\title{
Lease rentals and withholding tax
}

\author{
J.D.B. Oliver, Coopers \& Lybrand Deloitte, London
}

The imposition of withholding tax by a source state should ideally result in no more than an apportionment of the taxing rights between the state of source and the state of residence. If, however, the rate of withholding tax is set too high and the recipient has business expenses to set against the income the result can be double taxation. The level of credit in the country of residence is restricted to the tax on the net profit and the excess withholding tax goes unrelieved.

The issue is a familiar one and it reappeared in the course of discussions on the Taxation of Cross Border Leasing at the recent International Fiscal Association Congress in Stockholm. The Congress noted that states have not generally followed the OECD recommendation of 13 September 1983 that these payments should be free of tax in the source state in the absence of a permanent establishment. More often, it noted, in sharp contrast with those recommendations, they have continued to levy withholding taxes on rentals of moveable property. The congress encouraged states to follow the OECD recommendation but also recommended that where this cannot be achieved the rate of tax should be limited to a low rate so that full credit can normally be obtained in the residence state. Alternatively the lessor should be allowed to elect to be taxed at domestic rates of tax on its net income, after deduction of attributable expenses including finance costs.

The option to be taxed on net income is surely a reasonable one. It prevents the source state seeking to tax more than the net profits accruing to the recipient and thus causing the 'excess' tax mentioned above.

It may also be worth examining further the limitation on credit in the state of residence. It has been argued elsewhere that the tax credit is not unlimited. ${ }^{*}$ It may not exceed that part of the income tax that is attributable to the income which has been taxed in the country of source. Is the term income when used here applied in the sense of gross income or net income? Since the dividend and interest articles, for example, where they allow a withholding tax on such payments proceed by reference to the amount of the payment, i.e. the gross income, the term income as it arises in the credit article should be applied in the same way. On that basis if a residence state has allowed in the treaty negotiations, a source state to impose a high rate of withholding tax it cannot escape the consequences of that high rate by seeking to limit the credit in the residence state to tax on the net income. The withholding tax is levied on the gross income and the credit should be given by reference to the same measure. While this view may be disputed by the tax authorities in many territories, it is at least for consideration whether they should not accept the logic of applying a limitation of credit on this basis in those treaties where they have, perhaps because of other aspects of the treaty negotiations, had to concede a rather higher rate of withholding tax that would normally be appropriate.

Another point which emerges is that it is slightly curious at first sight that lease rentals should be included in the model royalty article. If taxation is only to be in the state of residence then it makes no difference but in other cases it does make it more difficult to differentiate the treatment of lease rentals and the treatment of true royalties. It may be that in some negotiations the justification for a tax in the source state on royalties is stronger than the case for a tax on these rentals. Therefore, if the two categories of income were separated and dealt with in separate articles of the treaty, and thus dealt with separately in negotation, it might be easier to achieve a lower or nil rate of withholding tax on these payments. Such a separation would have to be approached with care. Detaching lease payments in this way might introduce an argument that they are more analog to income from immovable property, which is taxable in the source state under the OECD model.

\footnotetext{
* Helmut Becker: 'The consideration of business expenses for tax credit under a tax teaty'. The Journal of Strategy in International Taxation (1987) Vol. 3 No. 2.
} 
In summary, there is a strong case for states following the OECD recommendation. Where they are unable to do so there is an equally strong case for action to eliminate double taxation which might arise because the withholding tax is set at too high a rate. This mitigating action might be either to reduce the rate itself, allow an alternative of taxation in the source state by reference to net income, or relax the limitations on credit in the residence state so that the credit is by reference to tax on gross income. 